\title{
The $\left(\mathrm{Ca}^{2+}+\mathrm{Mg}^{2+}\right)$-stimulated ATPase of the rat parotid endoplasmic reticulum
}

\author{
Pangajavalli THIYAGARAJAH and Soh Chan LIM \\ Department of Biochemistry, Faculty of Medicine, National University of Singapore, Lower Kent Ridge Road, Singapore 0511
}

\begin{abstract}
A membrane fraction enriched in endoplasmic reticulum was prepared from rat parotid glands by using sucrose-gradient centrifugation. The fraction showed a 10 -fold increase in specific activity of NADPH: cytochrome $c$ reductase activity over that of tissue homogenates and minimal contamination with plasma membranes or mitochondria. The endoplasmic reticulum fraction possessed both $\mathbf{M g}^{2+}$-stimulated ATPase as well as $\mathrm{Ca}^{2+}, \mathrm{Mg}^{2+}-\mathrm{ATPase}\left[\left(\mathrm{Ca}^{2+}+\mathrm{Mg}^{2+}\right)\right.$-stimulated ATPase] activity. $\mathrm{The}^{\mathrm{Ca}^{2+}, \mathrm{Mg}^{2+}-\mathrm{ATPase} \text { required }}$ 2-5 mM- $\mathrm{Mg}^{2+}$ for optimal activity and was stimulated by submicromolar concentrations of free $\mathrm{Ca}^{2+}$. The $K_{\mathrm{m}}$ for free $\mathrm{Ca}^{2+}$ was $0.55 \mu \mathrm{M}$ and the average $V_{\max }$. was $60 \mathrm{nmol} / \mathrm{min}$ per $\mathrm{mg}$ of protein. The $K_{\mathrm{m}}$ for ATP was $0.11 \mathrm{mM}$. Other nucleotides, such as GTP, CTP or ADP, could not substitute for ATP in supporting the $\mathrm{Ca}^{2+}$-activated nucleotidase activity. Increasing the $\mathrm{K}^{+}$concentration from 0 to $100 \mathrm{mM}$ caused a 2-fold activation of the $\mathrm{Ca}^{2+}, \mathrm{Mg}^{2+}$-ATPase. Trifluoperazine, $\mathrm{W}_{7}$ [N-(6-aminohexyl)-5-chloronaphthalene-1sulphonamide] and vanadate inhibited the enzyme. The concentration of trifluoperazine and vanadate required for $50 \%$ inhibition of the ATPase were $52 \mu \mathrm{M}$ and $28 \mu \mathrm{M}$ respectively. Calmodulin, cyclic AMP, cyclic AMP-dependent protein kinase and inositol 1,4,5-trisphosphate had no effect on the ATPase. The properties of the $\mathrm{Ca}^{2+}, \mathrm{Mg}^{2+}$-ATPase were distinct from those of the $\mathrm{Mg}^{2+}$-ATPase, but comparable with those reported for the parotid endoplasmic-reticulum $\mathrm{Ca}^{2+}$-transport system [Kanagasuntheram \& Teo (1982) Biochem. J. 208, 789-794]. The results suggest that the $\mathrm{Ca}^{2+}, \mathrm{Mg}^{2+}$-ATPase is responsible for driving the ATP-dependent $\mathrm{Ca}^{2+}$ accumulation by this membrane.
\end{abstract}

\section{INTRODUCTION}

In recent years, ATP-driven $\mathrm{Ca}^{2+}$-transport systems located on the plasma membrane or the endoplasmic reticulum have been identified in a variety of tissues, including the liver (Moore et al., 1975; Dawson, 1982; Lotersztajn et al., 1984), adipocyte (Bruns et al., 1976; Pershadsingh et al., 1980a), pancreatic islet (Pershadsingh et al., 1980b; Kotagal et al., 1982), parotid (Selinger et al., 1970; Kanagasuntheram \& Teo, 1982a,b) and submaxillary (Terman \& Gunter, 1983). These $\mathrm{Ca}^{2+}$ pumps are believed to function in conjunction with the $\mathrm{Ca}^{2+}$-transport system of the mitochondrial inner membrane in maintaining intracellular free $\mathrm{Ca}^{2+}$ concentrations at submicromolar levels. In addition, they also participate in the redistribution of intracellular $\mathrm{Ca}^{2+}$ that often accompanies hormonal or neural stimulation of tissues. Recent studies on liver (Burgess et al., 1984; Joseph et al., 1984) and pancreatic acinar (Streb et al., 1983) cells have shown that the endoplasmic-reticular $\mathrm{Ca}^{2+}$ pool is the major source of $\mathrm{Ca}^{2+}$ mobilized by myo-inositol 1,4,5-trisphosphate $\left(\mathrm{IP}_{3}\right)$ and that $\mathrm{IP}_{3}$ can induce rapid release of $\mathrm{Ca}^{2+}$ from isolated microsomes (Dawson \& Irvine, 1984; Prentki et al., 1984). Whereas these effects of $\mathrm{IP}_{3}$ on endoplasmic-reticulum $\mathrm{Ca}^{2+}$ flux are transient, more prolonged effects of hormonal stimulation have also been reported. In the rat liver, for example, $\mathrm{Ca}^{2+}$ accumulation by the microsomal fraction is increased after stimulation of the liver cells with glucagon (Waltenbaugh et al., 1980) and decreased after exposure to insulin (Taylor et al., 1979).

In common with the $\mathrm{Ca}^{2+}$-pumping ATPase of the sarcoplasmic reticulum (see review by De Meis \& Inesi, 1982) the translocation of $\mathrm{Ca}^{2+}$ across the endoplasmic reticulum of cells is probably driven by $\mathrm{Ca}^{2+}$-activated ATPases. In some tissues, such as liver and adipose tissue (Black et al., 1980; Dawson \& Fulton, 1983), endoplasmicreticulum- or microsomal-membrane-associated $\mathrm{Ca}^{2+}$ activated ATPases have been identified and shown to have properties similar to those of the corresponding $\mathrm{Ca}^{2+}$ pump. Further purification and reconstitution of these transport systems are, however, necessary before the identity of the $\mathrm{Ca}^{2+}$-activated ATPases and the $\mathrm{Ca}^{2+}$ pumps can be unequivocally demonstrated.

The rat parotid acinar cell possesses an extensive endoplasmic-reticular network containing a relatively active $\mathrm{Ca}^{2+}$-transporting system (Kanagasuntheram \& Teo, 1982a). $\mathrm{Ca}^{2+}$ transport by this membrane is likely to be important not only in maintaining intracellular free $\mathrm{Ca}^{2+}$ at submicromolar levels, but also in releasing $\mathrm{Ca}^{2+}$ in response to $\mathrm{Ca}^{2+}$-mobilizing agonists. The mechanism by which this pump translocates $\mathrm{Ca}^{2+}$ has not been investigated, and the $\mathrm{Ca}^{2+}$-dependent ATPase that presumably catalyses this translocation has not been characterized. We present here some results of our studies aimed at identifying and characterizing the $\mathrm{Ca}^{2+}$-activated ATPase of this membrane. 


\section{EXPERIMENTAL}

\section{Materials}

${ }^{45} \mathrm{CaCl}_{2}$ was obtained from New England Nuclear, Boston, MA, U.S.A. All biochemicals were from the Sigma Chemical Co., St. Louis, MO, U.S.A. Calmodulin was a gift from Dr. J. Wang. $\mathbf{I P}_{3}$ was prepared from human erythrocytes as described by Downes et al. (1982).

\section{Methods}

Subcellular fractionation. A parotid membrane fraction enriched in endoplasmic reticulum was prepared by using a sucrose density gradient. Parotid glands were dissected from four to eight male Wistar rats that had been starved overnight, cleaned and homogenized in $0.25 \mathrm{M}$-sucrose/ $10 \mathrm{~mm}$-Tris/ $\mathrm{HCl}$ (pH 7.4)/0.1 mM-dithiothreitol as described previously (Kanagasuntheram \& Teo, 1982b). The homogenate was centrifuged at $10000 \mathrm{~g}$ for $10 \mathrm{~min}$ and the supernatant removed carefully and re-centrifuged at $30000 \mathrm{~g}$ for $20 \mathrm{~min}$. The microsomal pellet was suspended in $2 \mathrm{ml}$ of the homogenizing buffer and layered over a step gradient consisting of $2 \mathrm{ml}$ of $1.5 \mathrm{M}$-sucrose/10 mMTris/HCl ( $\mathrm{pH}$ 7.4)/0.1 mM-dithiothreitol overlayed with similar buffer containing $0.5 \mathrm{M}$-sucrose. After centrifuging at $200000 \mathrm{~g}$ for $1 \mathrm{~h}$ in a Beckman SW 41 rotor, the pellet containing the endoplasmic-reticulum membrane was resuspended by gentle homogenization in $1-2 \mathrm{ml}$ of the homogenizing buffer and used immediately for enzyme and other assays. All stages of the isolation procedure were carried out at $4^{\circ} \mathrm{C}$.

ATPase assay. The $\mathrm{Ca}^{2+}, \mathrm{Mg}^{2+}$-ATPase was determined by measuring the difference in the rate of release of $P_{i}$ from ATP by membranes incubated in assay buffer containing $0.2 \mathrm{mM}-\mathrm{CaCl}_{2}$ and $0.2 \mathrm{mM}$-EGTA $(8.6 \mu \mathrm{M}$ free $\mathrm{Ca}^{2+}$ ) or 0.2 mM-EGTA alone. The free $\mathrm{Ca}^{2+}$ concentration was calculated by a computer program using stability constants as given by Sillén \& Martell (1971). Unless otherwise stated, all assays were carried out at $37^{\circ} \mathrm{C}$ in $0.5 \mathrm{ml}$ of assay buffer of the following composition: $100 \mathrm{~mm}-\mathrm{KCl}, 20 \mathrm{~mm}-\mathrm{Hepes}, \mathrm{pH} 6.8$, $2 \mathrm{mM}-\mathrm{MgCl}_{2}, 1 \mathrm{mM}-\mathrm{ATP}, 1 \mu \mathrm{g}$ of oligomycin, the appropriate concentrations of $\mathrm{CaCl}_{2}$ and EGTA and about $30 \mu \mathrm{g}$ of endoplasmic-reticulum protein. The membranes were preincubated for $10 \mathrm{~min}$ in assay buffer lacking ATP. The reaction was initiated by addition of
ATP and after incubating for $30 \mathrm{~min}, 0.25 \mathrm{ml}$ of $5 \%$ $(w / v)$ trichloroacetic acid was added to terminate the reaction. The tubes were chilled and centrifuged to remove precipitated proteins. About $100-500 \mu \mathrm{l}$ of the supernatant fraction was used for the determination of $P_{i}$ released by a modification of the method of Baginski et al. (1967). All the ATPase assays were carried out in triplicate and ATP hydrolysis was limited to less than $20 \%$ of the amount added. When required, blanks to which the trichloroacetic acid solution was added before addition of ATP were used to correct for endogenous $\mathbf{P}_{\mathbf{i}}$ present in the assay system.

Enzyme and other assays. ${ }^{45} \mathrm{Ca}^{2+}$ uptake was determined as described previously (Kanagasuntheram \& Teo, $1982 a$ ) in medium containing $20 \mu \mathrm{M}^{-45} \mathrm{CaCl}_{2}$. Protein was determined by the method of Lowry et al. (1951), with bovine serum albumin as standard. 5'-Nucleotidase activity was measured as described by Widnell \& Unkeless (1968), and NADPH:cytochrome $c$ reductase by the method of Strobel \& Dignan (1978). One unit of enzyme activity is defined as the amount of enzyme required to convert $1 \mu \mathrm{mol}$ of substrate into product in $1 \mathrm{~min}$ under the stated assay conditions.

\section{RESULTS}

\section{Purification of endoplasmic-reticulum membranes}

The use of a sucrose step gradient enabled us to obtain a parotid membrane fraction that was highly enriched in NADPH:cytochrome $c$ reductase activity (see Table 1). Plasma-membrane-associated 5'-nucleotidase, which was a major contaminant in our previous preparation (Kanagasuntheram \& Teo, 1982a), was effectively removed from the endoplasmic-reticulum pellet, since most of this activity was retained at the interface between $0.5 \mathrm{M}$ - and $1.5 \mathrm{M}$-sucrose solutions. About $30 \%$ of the NADPH:cytochrome $c$ reductase activity of the $30000 \mathrm{~g}$ pellet, representing about $11 \%$ of the total activity present in the homogenate, was recovered in the purified endoplasmic-reticulum fraction. This fraction showed a 10-fold increase in the specific activity of NADPH:cytochrome $c$ reductase activity compared with that of tissue homogenates and a 1.6-fold increase compared with that of the $30000 \mathrm{~g}$ fraction. Corresponding to the

\section{Table 1. Distribution of enzyme markers and ${ }^{45} \mathrm{Ca}^{2+}$-transport activity in parotid subcellular fractions}

Parotid glands were homogenized in $0.25 \mathrm{M}$-sucrose $/ 10 \mathrm{~mm}$-Tris/ $\mathrm{HCl} / 0.1 \mathrm{~mm}$-dithiothreitol, pH 7.4, and fractionated as described under 'Methods'. The activities of NADPH: cytochrome c reductase, $5^{\prime}$-nucleotidase and ${ }^{45} \mathrm{Ca}^{2+}$ uptake by the $30000 \mathrm{~g}$ microsomal pellet and the purified endoplasmic-reticulum fraction were determined. Results shown are means \pm S.E.M. for the numbers of preparations shown in parentheses. Abbreviation: N.D., not determined.

\begin{tabular}{|c|c|c|c|}
\hline \multirow[b]{2}{*}{ Parameter } & \multicolumn{3}{|c|}{ Value } \\
\hline & $\begin{array}{l}\text { Subcellular } \\
\text { fraction... Tissue homogenate }\end{array}$ & $\begin{array}{c}30000 \mathrm{~g} \\
\text { pellet }\end{array}$ & $\begin{array}{l}\text { Endoplasmic } \\
\text { reticulum }\end{array}$ \\
\hline $\begin{array}{l}\text { NADPH:cytochrome } c \\
\text { reductase (munit/mg } \\
\text { of protein) }\end{array}$ & $2.96 \pm 0.1(4)$ & $18.3 \pm 1.1(3)$ & $28.3 \pm 1.7(3)$ \\
\hline $\begin{array}{l}5^{\prime}-\text { Nucleotidase (munit/mg of protein) } \\
{ }^{45} \mathrm{Ca}^{2+} \text { uptake ( } \mathrm{nmol} / \mathrm{min} \\
\text { of protein) }\end{array}$ & $22.4 \pm \frac{1.7(3)}{\text { N.D. }}$ & $\begin{array}{l}64.8 \pm 7.2(3) \\
10.2 \pm 1.4(4)\end{array}$ & $\begin{array}{c}7.8 \pm 1.6(3) \\
18.2 \pm 1.6(14)\end{array}$ \\
\hline
\end{tabular}




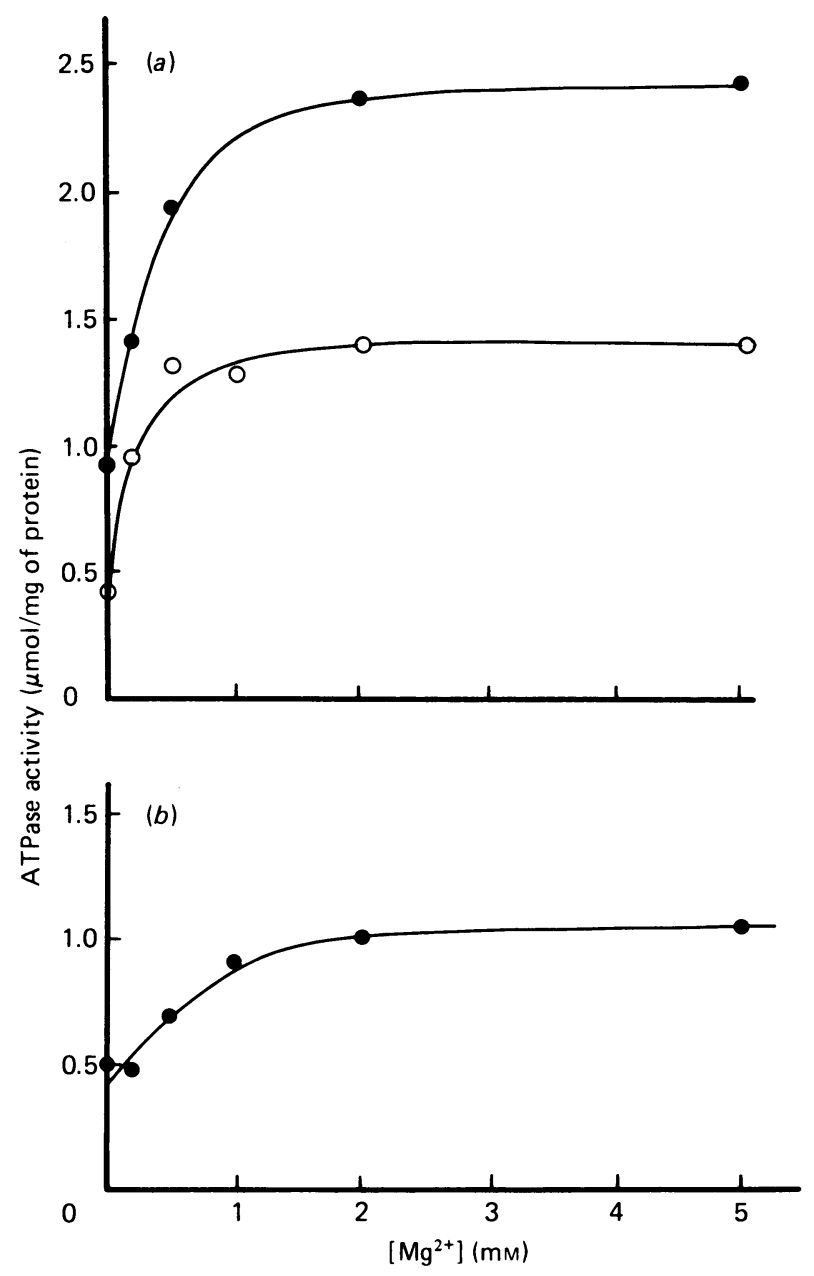

Fig. 1. Effect of $\mathrm{Mg}^{2+}$ concentration on $\mathrm{Mg}^{2+}$-ATPase and $\mathrm{Ca}^{2+}, \mathrm{Mg}^{2+}$-ATPase activities of parotid endoplasmicreticulum membranes

Endoplasmic-reticulum membranes were incubated in ATPase assay buffer containing $0.2 \mathrm{~mm}$-EGTA or $0.2 \mathrm{~mm}$ EGTA and $0.2 \mathrm{~mm}-\mathrm{CaCl}_{2}$ and various amounts of $\mathrm{Mg}^{2+}$ as indicated. $P_{i}$ released after 30 min was determined as described under 'Methods'. The $\mathrm{Ca}^{2+}, \mathrm{Mg}^{2+}-\mathrm{ATPase}$ was calculated as the difference in the rate of $P_{i}$ release in medium containing $\mathrm{Ca}^{2+}$ and that lacking it. (a): $\bigcirc$, $\mathrm{Mg}^{2+}$-ATPase; $, \mathrm{Ca}^{2+}, \mathbf{M g}^{2+}$-ATPase and $\mathrm{Mg}^{2+}$-ATPase. (b): $, \mathrm{Ca}^{2+}, \mathrm{Mg}^{2+}$-ATPase. Results shown are the means of triplicate determinations in a representative experiment.

increase in activity of this enzyme, ${ }^{45} \mathrm{Ca}^{2+}$ uptake by the purified endoplasmic reticulum was also increased by about 1.8-fold compared with that of the $30000 \mathrm{~g}$ fraction. For reasons that are unclear at present, the rate of ${ }^{45} \mathrm{Ca}^{2+}$ uptake by endoplasmic-reticulum vesicles isolated by this procedure was initially less than $6 \mathrm{nmol} / \mathrm{min}$ per $\mathrm{mg}$ of protein. Preincubation in the assay buffer (lacking ${ }^{45} \mathrm{Ca}^{2+}$ ), however, resulted in rapid activation of the uptake mechanism until a constant rate of about $18 \mathrm{nmol} / \mathrm{min}$ per $\mathrm{mg}$ of protein was achieved after $20-30 \mathrm{~min}$. The values quoted in Table 1 are the rates of ${ }^{45} \mathrm{Ca}^{2+}$ uptake by membrane vesicles that had been activated by prior incubation in assay buffer for $20 \mathrm{~min}$. There was no effect of preincubation on the rate of ${ }^{45} \mathrm{Ca}^{2+}$ uptake by the $30000 \mathrm{~g}$ pellet.

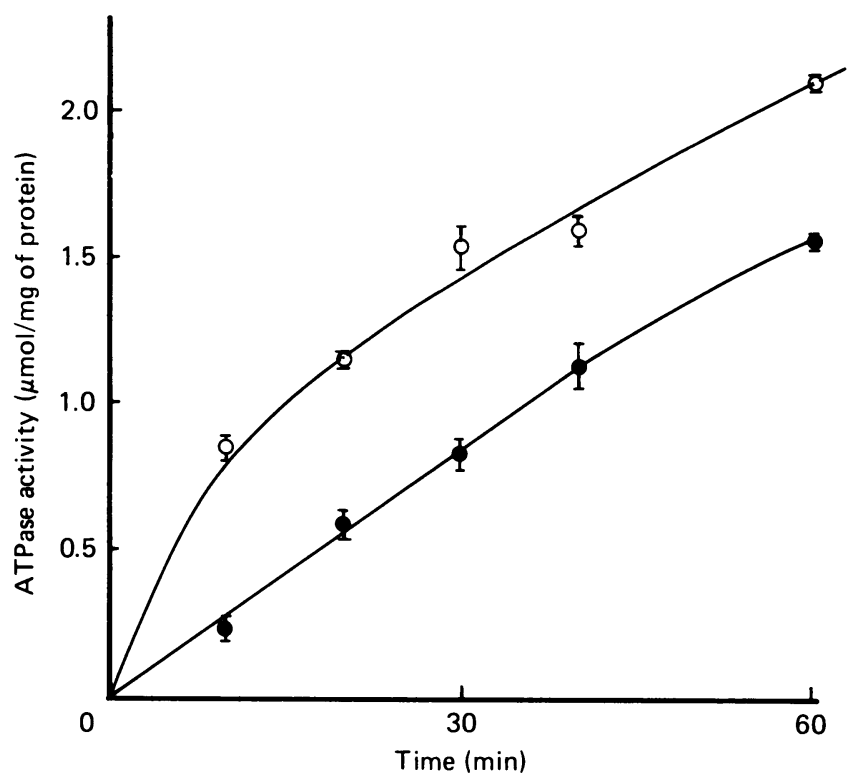

Fig. 2. Time course of $\mathrm{Mg}^{2+}-\mathrm{ATPase}$ and $\mathrm{Ca}^{2+}, \mathrm{Mg}^{2+}-\mathrm{ATPase}$ activities

Parotid endoplasmic-reticulum membranes were incubated at $37^{\circ} \mathrm{C}$ in assay buffer containing $0.2 \mathrm{~mm}$-EGTA or $0.2 \mathrm{~mm}$-EGTA and $0.2 \mathrm{~mm}-\mathrm{CaCl}_{2}$. At various times, the reaction was terminated and ATPase activity determined. Results are the means \pm S.E.M. of three determinations of a representative experiment. $\mathrm{O}, \mathrm{Mg}^{2+}$-ATPase; $\mathrm{Ca}^{2+}, \mathrm{Mg}^{2+}$-ATPase.

Characterization of the $\mathrm{Mg}^{2+}-\mathrm{ATPase}$ and $\mathrm{Ca}^{2+}$, $\mathrm{Mg}^{2+}$-ATPAse

Fig. 1 shows the effect of various amounts of added $\mathrm{Mg}^{2+}$ on the basal and $\mathrm{Ca}^{2+}$-activated ATPase activities. In assay buffer containing $0.2 \mathrm{~mm}$-EGTA, some hydrolysis of ATP occurred even when no added $\mathrm{Mg}^{2+}$ or $\mathrm{Ca}^{2+}$ was present. This residual activity probably represents ATPase activity that can be sustained by the small amount of endogenous $\mathrm{Mg}^{2+}$ present on the membrane, since it was completely abolished in the presence of $0.2 \mathrm{~mm}$-CDTA. Addition of $\mathrm{Mg}^{2+}$ resulted in a steady increase in the rate of ATP hydrolysis, with maximal ATPase activity occurring at $0.5 \mathrm{~mm}$ or higher concentration of $\mathrm{Mg}^{2+}$. The mean rate of ATP hydrolysis by membranes incubated with $2 \mathrm{mM}-\mathrm{Mg}^{2+}$ was $1.53 \pm 0.21 \mu \mathrm{mol} / 30 \mathrm{~min}$ per $\mathrm{mg}$ of protein (mean \pm S.E.M., $n=7$ ). This activity is referred to as the 'basal' or ' $\mathrm{Mg}^{2+}$-ATPase' activity. Addition of $\mathrm{CaCl}_{2}$ to give a free $\mathrm{Ca}^{2+}$ concentration of $8.6 \mu \mathrm{M}$ stimulated the ATPase activity. Although some $\mathrm{Ca}^{2+}$-activated ATPase activity was detectable even in the absence of added $\mathrm{Mg}^{2+}$, optimal $\mathrm{Ca}^{2+}, \mathrm{Mg}^{2+}$-ATPase activity required $2-5 \mathrm{~mm}-\mathrm{Mg}^{2+}$. In medium containing $2 \mathrm{~mm}-\mathrm{Mg}^{2+}$, the mean $\mathrm{Ca}^{2+}, \mathrm{Mg}^{2+}$-ATPase activity of the parotid endoplasmic-reticulum fraction was $1.23 \pm 0.09 \mu \mathrm{mol} /$ $30 \mathrm{~min}$ per $\mathrm{mg}$ of protein (mean \pm S.E.M., $n=26)$; the activities of different membrane preparations ranged from $0.54 \mu \mathrm{mol} / 30 \mathrm{~min}$ per $\mathrm{mg}$ of protein to $1.91 \mu \mathrm{mol} /$ $30 \mathrm{~min}$ per $\mathrm{mg}$ of protein.

Oligomycin at a concentration of $2 \mu \mathrm{g} / \mathrm{ml}$ had no effect on the endoplasmic reticulum $\mathrm{Ca}^{2+}, \mathrm{Mg}^{2+}$-ATPase. This inhibitor of the mitochondrial ATPase was, however, 


\section{Table 2. Nucleotidase activity of endoplasmic-reticulum membranes}

Parotid membranes were preincubated for $10 \mathrm{~min}$ in assay buffer containing all additions except ATP. Nucleotidase activity was initiated by addition of the nucleotide as indicated above, at a final concentration of $1 \mathrm{~mm}$. $P_{i}$ released during 30 min of incubation was determined. Appropriate blanks in which the reaction was terminated with trichloroacetic acid before addition of nucleotide were used to correct for endogenous $P_{1}$. Results are means \pm S.E.M. of six determinations.

Nucleotidase activity

( $\mu \mathrm{mol}$ of $\mathrm{P}_{\mathrm{i}} / 30 \mathrm{~min}$ per $\mathrm{mg}$ of protein)

$\overline{\mathrm{Mg}^{2+} \text {-stimulated } \quad\left(\mathrm{Ca}^{2+}-\mathrm{Mg}^{2+}\right) \text {-stimulated }}$

\begin{tabular}{lll}
\hline 1 mM-AMP & $0.33 \pm 0.03$ & 0 \\
1 mM-ADP & $0.64 \pm 0.03$ & $0.03 \pm 0.02$ \\
1 mM-ATP & $1.80 \pm 0.12$ & $0.64 \pm 0.05$ \\
1 mM-CTP & $1.87 \pm 0.14$ & $0.05 \pm 0.01$ \\
1 mM-GTP & $2.29 \pm 0.16$ & $0.03 \pm 0.01$ \\
1 mM-GTP + mM-ATP & $2.43 \pm 0.12$ & $0.41 \pm 0.08$
\end{tabular}

routinely included in the assay buffer to eliminate any interference from mitochondrial ATPase activity; $2 \mathrm{~mm}$ Ruthenium Red, an inhibitor of mitochondrial $\mathrm{Ca}^{2+}$ transport, also had no effect on the ATPase. In studies on the liver microsomal $\mathrm{Ca}^{2+}$-ATPase, Dawson \& Fulton (1983) noted that the presence of a $\mathrm{Ca}^{2+}$ ionophore or a $\mathrm{Ca}^{2+}$-precipitating agent such as oxalate was necessary for maximal expression of ATPase activity. The parotid endoplasmic-reticulum $\mathrm{Ca}^{2+}, \mathbf{M g}^{2+}$-ATPase activity, however, was not affected by the addition of either 2 or $8 \mu \mathrm{M}$-ionophore A23187 or 5 or $10 \mathrm{~mm}$-oxalate.

The $\mathrm{Ca}^{2+}$-activated-ATPase activity of the endoplasmic-reticulum membrane fraction remained stable when membranes were stored in ice for up to $4 \mathrm{~h}$. Freezing and storage overnight at $-70^{\circ} \mathrm{C}$, however, resulted in a 15-20\% loss of activity. Most of the experiments were therefore done on freshly isolated membranes.

\section{Time course of ATP hydrolysis}

Fig. 2 shows the time course of ATP hydrolysis by membranes incubated in the presence and in the absence of added $\mathrm{Ca}^{2+}$. ATP hydrolysis in assay buffer lacking $\mathrm{Ca}^{2+}$ proceeded at a rapid rate during the initial $10 \mathrm{~min}$ of incubation. Thereafter, hydrolysis proceeded at a lower, but steady, rate of about $21 \mathrm{nmol} / \mathrm{min}$ per $\mathrm{mg}$ of protein for up to $40 \mathrm{~min}$. In contrast, $\mathrm{Ca}^{2+}$-activated ATP hydrolysis proceeded at a linear rate of $24 \mathrm{nmol} / \mathrm{min}$ per $\mathrm{mg}$ of protein throughout the first $40 \mathrm{~min}$. After $40 \mathrm{~min}$, both the basal $\mathrm{Mg}^{2+}$-ATPase as well as the $\mathrm{Ca}^{2+}, \mathrm{Mg}^{2+}$ ATPase activities showed a decline in their rates due to the depletion of ATP in the assay medium.

\section{Nucleotide specificity}

The ability of the parotid endoplasmic-reticulum fraction to hydrolyse nucleotides other than ATP is shown in Table 2. All the nucleotides tested were hydrolysed to various extents when incubated with membranes in buffer containing $2 \mathrm{~mm}-\mathrm{Mg}^{2+}$. Nucleotidase activities using AMP or ADP as substrates were relatively low compared with $\mathrm{Mg}^{2+}$-ATPase activity. CTP and GTP were hydrolysed at rates comparable with, or slightly greater than, that of ATP hydrolysis. When $\mathrm{Ca}^{2+}$ was also included in the assay buffer, there was no significant increase in the rate of hydrolysis of any of these nucleotides, indicating that none of these could substitute for ATP in driving the $\mathrm{Ca}^{2+}, \mathrm{Mg}^{2+}$-ATPase. Addition of $1 \mathrm{~mm}$-GTP together with $1 \mathrm{~mm}$-ATP inhibited the $\mathrm{Ca}^{2+}$-activated hydrolysis of ATP by about $43 \%$. When both nucleotides were present, $P_{i}$ released in the absence of added $\mathrm{Ca}^{2+}$ (presumably owing to the $\mathrm{Mg}^{2+}$-dependent hydrolysis of ATP as well as GTP) was also less than the sum of the rates of hydrolysis of ATP and GTP determined individually.

\section{Kinetic parameters}

The $K_{\mathrm{m}}$ for ATP was determined by measuring the $\mathrm{Mg}^{2+}$-ATPase and the $\mathrm{Ca}^{2+}, \mathrm{Mg}^{2+}$-ATPase activities in the presence of ATP concentrations ranging from 0.05 to $2 \mathrm{mM}$. In these experiments, the incubation time was decreased to $10 \mathrm{~min}$ and the protein concentration lowered to about $20 \mu \mathrm{g} / 0.5 \mathrm{ml}$ of assay mixture to ensure that ATP hydrolysis during incubation did not lead to significant changes in the concentration of the substrate. A Lineweaver-Burk transformation of the data points gave linear plots from which the $K_{\mathrm{m}}$ for ATP was calculated to be $0.11 \pm 0.2 \mathrm{mM}$ (mean \pm S.E.M., $n=3$ ) for the $\mathrm{Ca}^{2+}, \mathrm{Mg}^{2+}$-ATPase and $0.06 \pm 0.01 \mathrm{mM}$ for the $\mathrm{Mg}^{2+}$-ATPase. Fig. 3 shows the effect of varying the free $\mathrm{Ca}^{2+}$ concentration of the medium from 0.2 to $20 \mu \mathrm{M}$ on the $\mathrm{Ca}^{2+}, \mathrm{Mg}^{2+}$-ATPase activity. The $\mathrm{Ca}^{2+}$-activated ATPase activity increased as a function of free $\mathrm{Ca}^{2+}$ concentration until maximal rates were achieved at free $\mathrm{Ca}^{2+}$ concentrations greater than $5 \mu \mathrm{M}$. From kinetic analysis of three different membrane preparations, the $K_{\mathrm{m}}$ for $\mathrm{Ca}^{2+}$ was found to be $0.55 \pm 0.02 \mu \mathrm{M} ; V_{\max }$ for the same preparations ranged from 45 to $74 \mathrm{nmol} / \mathrm{min}$ per mg of protein, and the average $V_{\text {max. }}$ was $60 \pm 8 \mathrm{nmol} /$ min per $\mathrm{mg}$ of protein.

\section{Effects of $\mathrm{K}^{+}$and vanadate}

In previous studies on the parotid endoplasmicreticulum $\mathrm{Ca}^{2+}$-transport system (Kanagasuntheram \& Teo, 1982a), we observed that ${ }^{45} \mathrm{Ca}^{2+}$ uptake was markedly stimulated by $\mathrm{K}^{+}$. To determine whether the $\mathrm{Ca}^{2+}, \mathrm{Mg}^{2+}$-ATPase was similarly influenced by $\mathrm{K}^{+}$, $\mathrm{Ca}^{2+}$-activated-ATPase, activity was determined in the presence of various concentrations of added $\mathrm{K}^{+}$. As shown in Fig. 4, increasing the $\mathrm{K}^{+}$concentration from 0 to $100 \mathrm{~mm}$ stimulated the $\mathrm{Ca}^{2+}, \mathrm{Mg}^{2+}$-ATPase in a concentration-dependent manner. The activation profile was similar to that observed for the $\mathrm{Ca}^{2+}$-transport 


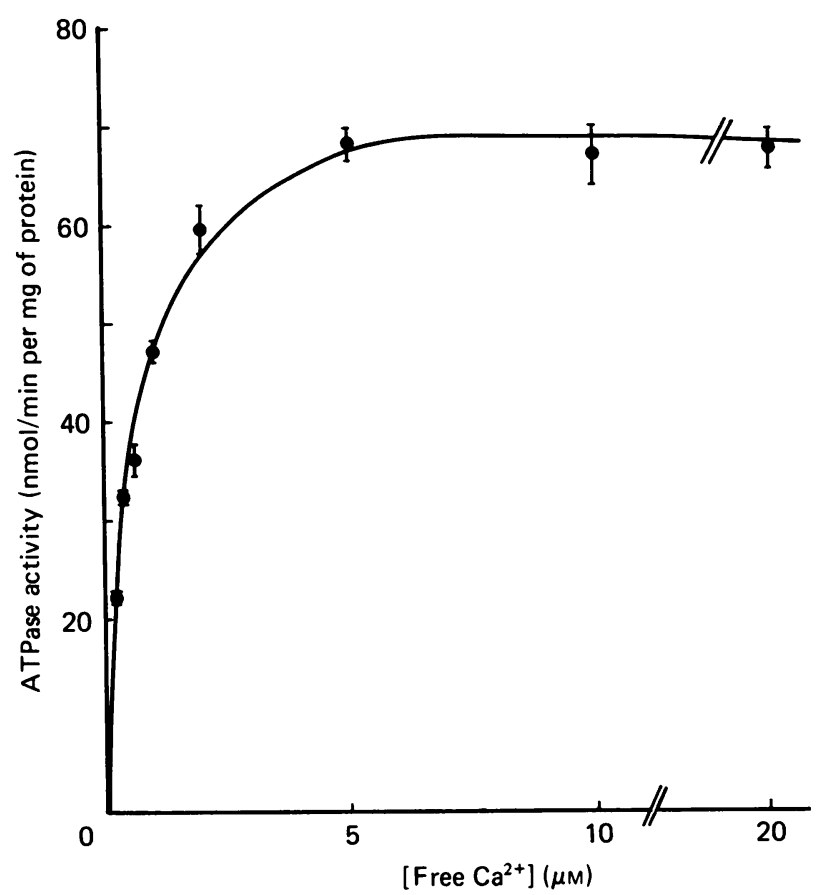

Fig. 3. $\mathrm{Ca}^{2+}$-dependence of the $\mathrm{Ca}^{2+}, \mathrm{Mg}^{2+}-\mathrm{ATPase}$ activity

Endoplasmic-reticulum membranes were incubated in assay buffer containing $0.2 \mathrm{mM}$-EGTA and various concentrations of $\mathrm{CaCl}_{2}$ to give the free $\mathrm{Ca}^{2+}$ concentrations indicated. $P_{i}$ released after $30 \mathrm{~min}$ of incubation was determined as described under 'Methods'. Results are the means \pm S.E.M. of three determinations on a representative preparation.

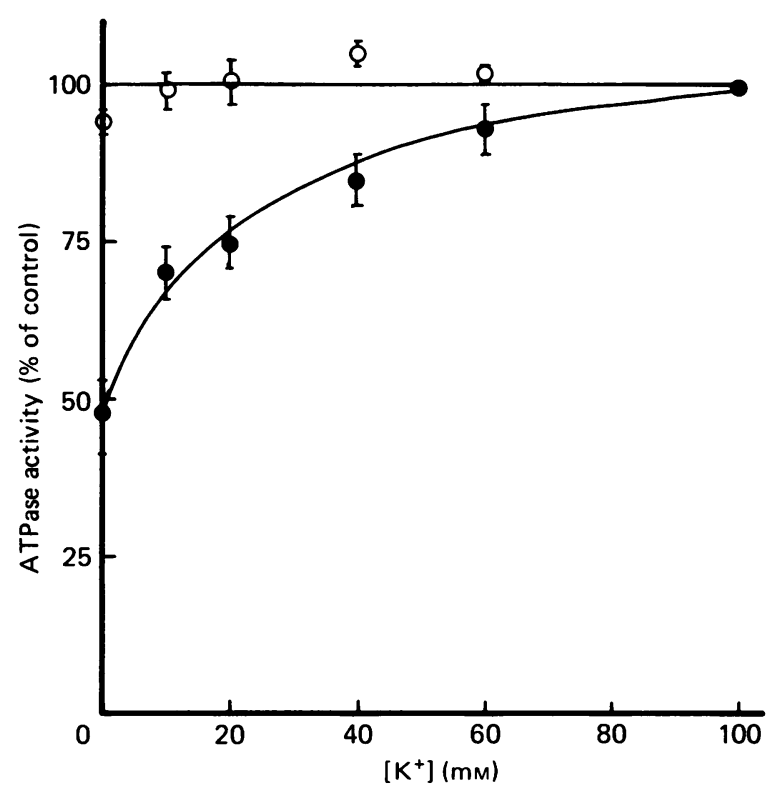

Fig. 4. Efiect of $\mathrm{K}^{+}$concentration on the $\mathrm{Mg}^{2+}-\mathrm{ATPase}$ and $\mathrm{Ca}^{2+}, \mathrm{Mg}^{2+}$-ATPase activities

ATPase activity was determined in assay medium buffered with Tris $/ \mathrm{HCl}$ instead of Hepes $/ \mathrm{KOH}$. The $\mathrm{KCl}$ concentration was varied from 0 to $100 \mathrm{~mm}$ and iso-osmolarity maintained by addition of compensating amounts of Tris/HCl. Results, which are the means \pm S.E.M. of three separate experiments, are expressed as a percentage of the ATPase activity in medium containing $100 \mathrm{~mm}-\mathrm{KCl}$. $\mathrm{O}$, Mg-ATPase; O, $\mathrm{Ca}^{2+}, \mathrm{Mg}^{2+}$-ATPase.

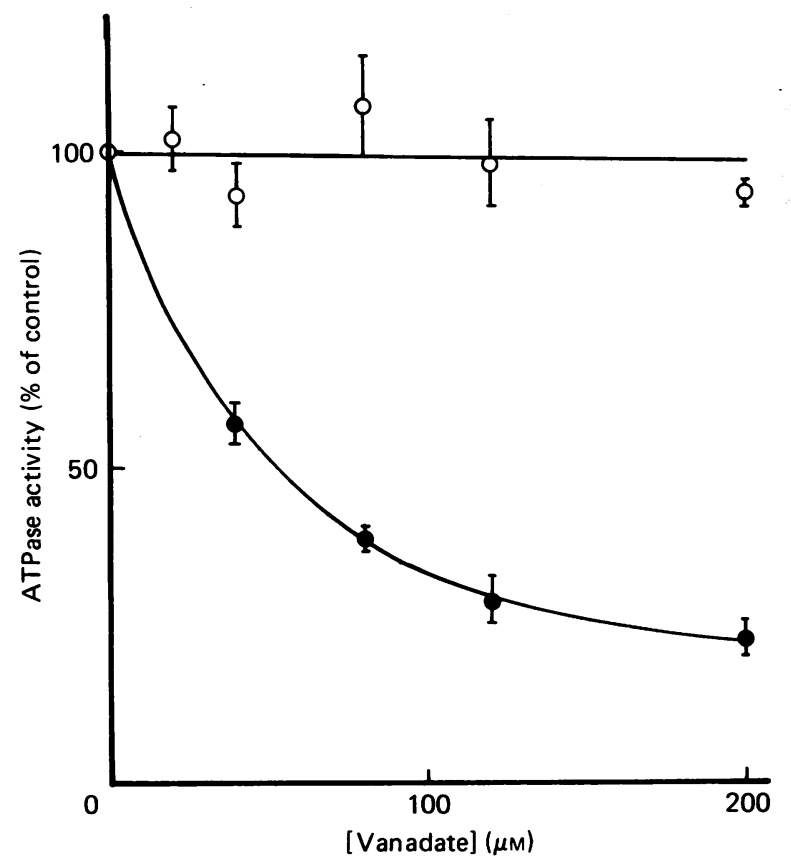

Fig. 5. Effect of vanadate on the $\mathrm{Mg}^{2+}-\mathrm{ATPase}$ and $\mathrm{Ca}^{2+}, \mathrm{Mg}^{2+}$ ATPase activities

Endoplasmic-reticulum membranes were preincubated for $10 \mathrm{~min}$ in assay buffer containing various concentrations of potassium orthovanadate. The reaction was initiated by addition of ATP, and $P_{1}$ released after 30 min of incubation was determined. ATPase activity is expressed as a percentage of the activity in the absence of vanadate. Results are means \pm S.E.M. of three different experiments. O, $\mathrm{Mg}^{2+}$-ATPase; $, \mathrm{Ca}^{2+}, \mathrm{Mg}^{2+}$-ATPase.

system, and the ATPase activity in medium containing $100 \mathrm{~mm}-\mathrm{K}^{+}$was about twice as great as that in medium lacking $\mathrm{K}^{+}$. When tested under similar conditions, $\mathrm{K}^{+}$failed to have any effect on the $\mathbf{M g}^{2+}$ ATPase activity.

Vanadate inhibited the $\mathrm{Ca}^{2+}, \mathrm{Mg}^{2+}-\mathrm{ATPase}$, but not the $\mathrm{Mg}^{2+}$-ATPase (Fig. 5). The sensitivity to inhibition by vanadate displayed by the $\mathrm{Ca}^{2+}, \mathrm{Mg}^{2+}$ ATPase was slightly greater than that reported for the corresponding $\mathrm{Ca}^{2+}$-transport system (Kanagasuntheram \& Teo, $1982 a$ ), particularly at higher concentrations of vanadate. Vanadate at $60 \mu \mathrm{M}$, for example, inhibited the $\mathrm{Ca}^{2+}, \mathrm{Mg}^{2+}$. ATPase by $72 \%$, compared with only $50 \%$ inhibition of the $\mathrm{Ca}^{2+}$-transport system. The $\mathrm{IC}_{50}$ (concentration of vanadate required for $50 \%$ inhibition of the $\mathrm{Ca}^{2+}, \mathrm{Mg}^{2+}$ ATPase) was $28 \mu \mathrm{M}$, which is about one order of magnitude greater than the $\mathrm{IC}_{50}$ quoted for plasmamembrane-associated $\mathrm{Ca}^{2+}$-activated ATPases, but is comparable with that of other endoplasmic-reticulum or sarcoplasmic-reticulum-associated $\mathbf{C a}^{2+}, \mathbf{M g}^{2+}$-ATPases (Caroni \& Carofoli, 1981a).

\section{Effects of trifluoperazine, $W_{7}$ and calmodulin}

The calmodulin antagonists trifluoperazine and $\mathrm{W}_{7}$ both inhibited the $\mathrm{Ca}^{2+}, \mathrm{Mg}^{2+}$-ATPase activity of the endoplasmic-reticulum membranes. Increasing the concentration of trifluoperazine from $10 \mu \mathrm{M}$ to $100 \mu \mathrm{M}$ caused progressively greater inhibition of the ATPase, and $52 \mu \mathrm{M}$-trifluoperazine inhibited the enzyme by $50 \%$ 


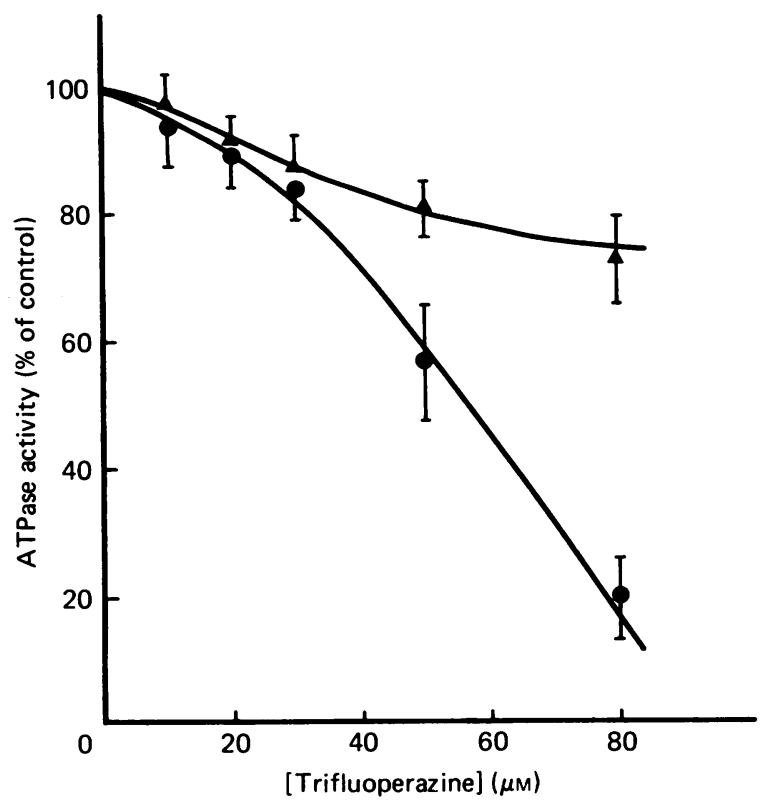

Fig. 6. Inhibition of $\mathrm{Mg}^{2+}-\mathrm{ATPase}$ and $\mathrm{Ca}^{2+}, \mathrm{Mg}^{2+}-\mathrm{ATPases}$ by trifluoperazine

Parotid membranes were pre-incubated in assay buffer containing 0 to $100 \mu \mathrm{M}$-trifluoperazine, and ATPase activity was determined as described under 'Methods'. Results are expressed as a percentage of the activity obtained in the absence of trifluoperazine, $\triangle, \mathrm{Mg}^{2+}$. ATPase; $, \mathrm{Ca}^{2+}, \mathrm{Mg}^{2+}$-ATPase.

(Fig. 6). At concentrations greater than $10 \mu \mathrm{M}$, trifluoperazine also caused some inhibition of the basal $\mathrm{Mg}^{2+}$-ATPase activity, although the magnitude of the inhibition was always substantially lower than that of the $\mathrm{Ca}^{2+}$-activated ATPase. These effects of trifluoperazine on the $\mathrm{Mg}^{2+}$-ATPase suggest that, at high concentrations, trifluoperazine may have non-specific effects on membrane ATPases that are not necessarily linked to its ability to antagonize calmodulin function.

$\mathrm{W}_{7}$ also inhibited the $\mathrm{Ca}^{2+}, \mathrm{Mg}^{2+}$-ATPase, but was less effective than trifluoperazine (results not shown). When added at a concentration of $50 \mu \mathrm{M}, \mathrm{W}_{7}$ inhibited the $\mathrm{Ca}^{2+}, \mathrm{Mg}^{2+}$-ATPase by $19 \%$.

Addition of pure calmodulin at a concentration of $2 \mu \mathrm{g} / \mathrm{ml}$ had no effect on the $\mathrm{Ca}^{2+}$-activated ATPase. In previous studies (Kanagasuntheram \& Teo, 1982b) it was found that calmodulin is tightly associated with the endoplasmic-reticulum-containing fraction. When this endogenous calmodulin was depleted by hypo-osmotic washing, the $\mathrm{Ca}^{2+}$-transporting activity of the membrane was lowered by about $70 \%$. Re-addition of calmodulin to the calmodulin-depeleted membranes resulted in partial re-activation of the $\mathrm{Ca}^{2+}$-transport activity. When a similar protocol of hypo-osmotic washing (twice with $0.1 \mathrm{~mm}$-EGTA/10 mM-Tris/ $\mathrm{HCl}, \mathrm{pH}$ 7.4) was adopted in the present studies, the $\mathrm{Ca}^{2+}, \mathrm{Mg}^{2+}$-ATPase activity of the purified endoplasmic-reticulum membrane was decreased by $36 \%$. Addition of exogenous calmodulin at a concentration of $2 \mu \mathrm{g} / \mathrm{ml}$, however, failed to restore the ATPase activity.

\section{Other properties}

Some $\mathrm{Ca}^{2+}$-pumping ATPases may be stimulated by phosphorylation by cyclic AMP-dependent protein kinase (Tada et al., 1974; Caroni \& Carafoli, 1981b) or by hormones that elevate intracellular cyclic AMP (Waltenbaugh et al., 1980). The effects of cyclic AMP and cyclic AMP-dependent protein kinase on the activities of the parotid endoplasmic-reticulum ATPases were therefore investigated. Incubation of the membranes in assay buffer containing $5 \mu \mathrm{M}$-cyclic AMP alone or $5 \mu \mathrm{M}$-cyclic AMP and cyclic AMP-dependent protein kinase $(10 \mu \mathrm{g} / \mathrm{ml})$ for up to $30 \mathrm{~min}$ had no significant effect on $\mathrm{Mg}^{2-}$-ATPase or $\mathrm{Ca}^{2+}, \mathrm{Mg}^{2+}-\mathrm{ATPase}$ activities. IP ${ }_{3}$, a potent stimulator of $\mathrm{Ca}^{2+}$ efflux from the endoplasmic reticulum of a variety of cell types (Prentki et al., 1984; Berridge \& Irvine, 1984), also had no effect on either ATPase over a $10 \mathrm{~min}$ incubation period when added at a concentration at $10 \mu \mathrm{M}$.

\section{DISCUSSION}

$\mathrm{A} \mathrm{Ca}^{2+}, \mathrm{Mg}^{2+}-\mathrm{ATPase}$ has been identified in a parotid membrane fraction highly enriched in endoplasmicreticulum membrane. Its properties were similar to those reported for the parotid endoplasmic-reticulum ATP-dependent $\mathrm{Ca}^{2+}$ pump (Kanagasuntheram \& Teo, 1982a,b), indicating that this ATPase is likely to be responsible for driving the $\mathrm{Ca}^{2+}$ pump. In addition to the $\mathrm{Ca}^{2+}, \mathrm{Mg}^{2+}$-ATPase, the membrane fraction also possessed $\mathrm{Mg}^{2+}$-ATPase activity that did not require $\mathrm{Ca}^{2+}$ for activity. The $\mathrm{Mg}^{2+}-\mathrm{ATPase}$ displayed different sensitivities to $\mathrm{K}^{+}$, vanadate and trifluoperazine and had a higher affinity for ATP compared with the $\mathrm{Ca}^{2+}$. activated ATPase. These distinguishing properties suggest that the $\mathrm{Mg}^{2+}-\mathrm{ATP}$ ase and the $\mathrm{Ca}^{2+}, \mathrm{Mg}^{2+}-\mathrm{ATPase}$ are two distinct enzymes. The nature and function of the $\mathrm{Mg}^{2+}-\mathrm{ATPase}$ are at present unclear.

Like the $\mathrm{Ca}^{2+}, \mathrm{Mg}^{2+}-\mathrm{ATPases}$ of other tissues, the partoid endoplasmic-reticulum ATPase displayed a high affinity for $\mathrm{Ca}^{2+}$. The $K_{\mathrm{m}}$ for $\mathrm{Ca}^{2+}$ of $0.55 \mu \mathrm{M}$ is comparable with the value of $0.5 \mu \mathrm{M}$ reported for the sarcoplasmic reticulum (see review by De Meis \& Inesi, 1982) and 0.6-1.2 $\mu \mathrm{M}$ reported for adipocyte endoplasmic reticulum (Black et al., 1980). In studies on the ATP-dependent $\mathrm{Ca}^{2+}$ pump of the parotid endoplasmic reticulum (Kanagasuntheram \& Teo, 1982a), the $K_{\mathrm{m}}$ for $\mathrm{Ca}^{2+}$ was found to be $3.7 \mu \mathrm{M}$. The discrepancy between this value and that obtained in the present study may be attributed to the different experimental conditions used in the two studies. $\mathrm{Ca}^{2+} /$ EGTA buffers were not employed in the studies on $\mathrm{Ca}^{2+}$ transport, and this may have led to an overestimation of the free $\mathrm{Ca}^{2+}$ concentration. Moreover, as reported for the erythrocyte membrane $\mathrm{Ca}^{2+}$ pump, EGTA itself may increase the $\mathrm{Ca}^{2+}$-binding affinity of transport ATPases (see review by Schatzmann, 1982).

The maximal rates of ATP hydrolysis by the parotid $\mathrm{Ca}^{2+}, \mathrm{Mg}^{2+}$-ATPase ranged from 45 to $74 \mathrm{nmol} / \mathrm{min}$ per $\mathrm{mg}$ of protein. These values are about 3-5 times higher than those reported for the $\mathrm{Ca}^{2+}$-activated ATPases of the endoplasmic reticulum of liver and adipose tissue (Black et al., 1980; Dawson \& Fulton, 1983). Muscle sarcoplasmic reticulum in which the $\mathrm{Ca}^{2+}$-pumping ATPase constitutes the major protein component, however, has a $V_{\max }$ for $\mathrm{Ca}^{2+}, \mathrm{Mg}^{2+}$-ATPase that is one to two orders of magnitude greater (Meissner, 1974).

Unlike the sarcoplasmic-reticulum $\mathrm{Ca}^{2+}$ pump, many non-muscle $\mathrm{Ca}^{2+}$-transport systems display a strict requirement for ATP (Moore et al., 1975; Penniston, 
1983). Other nucleotides, such as GTP, CTP or ITP, support little or no $\mathrm{Ca}^{2+}$-pumping activity. The parotid endoplasmic-reticulum $\mathrm{Ca}^{2+}, \mathbf{M g}^{2+}$-ATPase showed a similar narrow specificity with respect to nucleotide requirement, a property shared by the $\mathrm{Ca}^{2+}$ pump located on this membrane (P. Thiyagarajah \& S. C. Lim, unpublished work). The ability of added GTP to inhibit ATP hydrolysis by the $\mathrm{Ca}^{2+}, \mathrm{Mg}^{2+}$-ATPase suggested that a GTP-binding protein may regulate its activity, since there is increasing evidence that GTP-binding proteins similar to the regulatory proteins of the adenylate cyclase complex are involved in the action of $\mathrm{Ca}^{2+}$-mobilizing receptors (Berridge \& Irvine, 1984). We were, however, unable to detect any inhibitory effect of GTP or is analogue, guanosine $5^{\prime}$-[ $\beta \gamma$-imido]triphosphate, on the $\mathrm{Ca}^{2+}, \mathrm{Mg}^{2+}$-ATPase at concentrations lower than $0.2 \mathrm{mM}$ (P. Thiyagarajah \& S. C. Lim, unpublished work), indicating that the inhibitory effect observed with 1 mM-GTP may be due to direct antagonism of ATP interaction with the ATPase rather than an effect that is mediated through a GTP-binding regulatory protein.

The $\mathrm{Ca}^{2+}, \mathbf{M g}^{2+}$-ATPase, but not the $\mathbf{M g}^{2+}$-ATPase, was activated when the $\mathrm{K}^{+}$concentration in the assay buffer was increased from 0 to $100 \mathrm{mM}$. Sensitivity to activation by $\mathrm{K}^{+}$is shared by other intracellularmembrane-associated $\mathrm{Ca}^{2+}$-transport systems such as smooth muscle (Wibo et al., 1981), liver (Moore et al., 1975 ) and adipocyte (Pershadsingh \& McDonald, 1980), and it has been suggested that this property may be used to distinguish these $\mathrm{Ca}^{2+}$-transport systems from those which are located on the plasma membrane, since the latter generally show little or no sensitivity to $\mathbf{K}^{+}$. Another criterion that is often used to distinguish plasma-membrane $\mathrm{Ca}^{2+}$ pumps from those on the endoplasmic reticulum is their differential sensitivity to inhibition by vanadate. The plasma-membrane $\mathrm{Ca}^{2+}$ pumping ATPases are inhibited by more than $50 \%$ by a vanadate concentration of $2 \mu \mathrm{M}$ or less (Caroni \& Carafoli, 1981a; Michaelis et al., 1983), whereas those associated with intracellular membranes, such as the endoplasmic reticulum, require $10-100$ times higher concentrations of vanadate. In the present studies, the parotid endoplasmic-reticulum $\mathrm{Ca}^{2+}, \mathrm{Mg}^{2+}$-ATPase required a relatively high concentration of $28 \mu \mathrm{M}$-vanadate for $50 \%$ inhibition of activity.

The physiological mechanisms responsible for the regulation of the $\mathrm{Ca}^{2+}, \mathrm{Mg}^{2+}-\mathrm{ATPase}$ remain to be elucidated. Inhibition of the ATPase by the calmodulin antagonists trifluoperazine and $W_{7}$ suggest that calmodulin may regulate its activity. However, the concentration of trifluoperazine required for $50 \%$ inhibition of the ATPase was slightly higher than that required for inhibition of the parotid endoplasmic-reticulum $\mathrm{Ca}^{2+}$ pump (Kanagasuntheram \& Teo, 1982b) and some other calmodulin-regulated $\mathrm{Ca}^{2+}$-transport systems (Caroni \& Carafoli, 1981a; Terman \& Gunter, 1983). $\mathrm{IP}_{3}$, at concentrations sufficient to cause maximal release of $\mathrm{Ca}^{2+}$ from the endoplasmic reticulum of cells, failed to affect the activity of the $\mathrm{Ca}^{2+}, \mathrm{Mg}^{2+}$-ATPase. These observations suggest that the $\mathrm{Ca}^{2+}$-mobilizing second messenger probably acts on the $\mathrm{Ca}^{2+}$-efflux mechanism rather than the ATP-dependent uptake process. In a separate paper (Thiyagarajah \& Lim, 1984) we presented evidence that phosphatidylinositol 4,5-bisphosphate stimulates the $\mathrm{Ca}^{2+}, \mathrm{Mg}^{2+}$-ATPase of the parotid endoplasmic reticulum. Further studies are, however, necessary to establish clearly whether changes in the membrane content of this phospholipid serve as a physiological mechanism for regulating its activity.

\section{REFERENCES}

Baginski, F., Foa, P. P. \& Zak, B. (1967) Clin. Chim. Acta 15, $155-158$

Berridge, M. J. \& Irvine, R. F. (1984) Nature (London) 312, 315-321

Black, B. L., McDonald, J. M. \& Jarrett, L. (1980) Arch. Biochem. Biophys. 199, 92-102

Bruns, D. E., McDonald, J. M. \& Jarett, L. (1976) J. Biol. Chem. 251, 7191-7197

Burgess, G. M., Godfrey, P. P., McKinney, J. S., Berridge, M. J., Irvine, R. F. \& Putney, J. W. (1984) Nature (London) 309, 63-66

Caroni, P. \& Carafoli, E. (1981a) J. Biol. Chem. 256, 3263-3270

Caroni, P. \& Carafoli, E. (1981b) J. Biol. Chem. 256, 9371-9373

Dawson, A. P. (1982) Biochem. J. 206, 73-79

Dawson, A. P. \& Fulton, D. V. (1983) Biochem. J. 210, 405-410

Dawson, A. P. \& Irvine, R. F. (1984) Biochem. Biophys. Res. Commun. 120, 858-864

De Meis, L. \& Inesi, G. (1982) in Membrane Transport of Calcium (Carafoli, E., ed.), pp. 141-186, Academic Press, New York

Downes, C. P., Mussat, M. C. \& Michell, R. M. (1982) Biochem. J. 203, 169-177

Joseph, S. K., Thomas, A. P., Williams, R. J., Irvine, R. F. \& Williamson, J. R. (1984) J. Biol. Chem. 259, 3077-3081

Kanagasuntheram, P. \& Teo, T. S. (1982a) Biochem. J. 208, 789-794

Kanagasuntheram, P. \& Teo, T. S. (1982b) FEBS Lett. 141, 233-236

Kotagal, N., Patke, C., Landt, M., McDonald, J., Colca, J., Lacy, P. \& McDaniel, M. (1982) FEBS Lett. 137, 249-252

Lotersztajn, S., Epand, R. M., Mallat, A. \& Pecker, F. (1984) J. Biol. Chem. 259, 8195-8201

Lowry, O. H., Rosebrough, N. J., Farr, A. L. \& Randall, R. J. (1951) J. Biol. Chem. 193, 265-275

Meissner, G. (1974) Methods Enzymol. 31, 238-246

Michaelis, E. K., Michaelis, M. L., Chang, H. H. \& Kitos, T. (1983) J. Biol. Chem. 258, 6101-6108

Moore, L., Chen, T., Knapp, H. R. \& Landan, E. J. (1975) J. Biol. Chem. 250, 4562-4568

Penniston, J. J. (1983) in Calcium and Cell Function (Cheung, W. Y., ed.), pp. 100-149, Academic Press, New York

Pershadsingh, H. A. \& McDonald, J. M. (1980) J. Biol. Chem. 255, 4087-4093

Pershadsingh, H. A., Landt, M. \& McDonald, J. M. (1980a) J. Biol. Chem. 255, 8983-8986

Pershadsingh, H. A., McDaniel, M. L., Landt, M., Bry, C. G., Lacy, P. E. \& McDonald, J. M. (1980b) Nature (London) 288, 492-495

Prentki, M., Biden, T. J., Janic, D., Irvine, R. F., Berridge, M. J. \& Wolheim, C. B. (1984) Nature (London) 309, $562-564$

Schatzmann, H. J. (1982) in Membrane Transport of Calcium (Carafoli, E., ed.), pp. 41-108, Academic Press, New York

Selinger, Z., Naim, E. \& Lasser, M. (1970) Biochim. Biophys. Acta 203, 326-334

Sillén, L. G. \& Martell, A. E. (1971) Stability Constants of metal Ion Complexes, 2nd edition, The Chemical Society, London

Streb, H., Irvine, R. F., Berridge, M. J. \& Schulz, I. (1983) Nature (London) 306, 67-68

Strobel, H. W. \& Dignan, J. S. (1978) Methods Enzymol. 52, 89-96

Tada, M., Kirchberger, M. A., Repke, D. I. \& Katz, A. M. (1974) J. Biol. Chem. 249, 6174-6180 
Taylor, W. M., Bygrave, F. L., Blackmore, P. F. \& Exton, J. H. (1979) FEBS Lett. 104, 31-34

Terman, B. I. \& Gunter, T. E. (1983) Biochim. Biophys. Acta 730, $151-160$

Thiyagarajah, P. \& Lim, S. C. (1984) Biochem. Int. 9, 625630
Waltenbaugh, A. A., Lam, A., Hummel, L. \& Friedmann, N. (1980) Biochim. Biophys. Acta 630, 165-175

Wibo, M., Morel, N. \& Godfraind, T. (1981) Biochim. Biophys. Acta 649, 651-660

Widnell, C. C. \& Unkless, J. C. (1968) Proc. Natl. Acad. Sci. U.S.A. 61, 1050-1057

Received 4 September 1985/14 November 1985; accepted 12 December 1985 